Arq. Bras. Med. Vet. Zootec., v.56, n.2, p.183-186, 2004

\title{
Acquired vesicovaginal fistula secondary to ovariohysterectomy in a bitch: a case report
}

[Fistula vesicovaginal secundária à ovário-histerectomia em cadela: relato de caso]

\author{
C.R.F. Gadelha, A.P.C. Ribeiro, M.F. Apparicio, G.J. Covizzi, W.R.R. Vicente* \\ Faculdade de Ciências Agrárias e Veterinárias - UNESP \\ Via de Acesso Prof. Paulo Donato Castellane, s/n \\ 14884-900 - Jaboticabal, SP
}

\begin{abstract}
A seven-year-old bitch was referred for investigation of a two-month history of strangury. Clinical signs had developed within two days of elective ovariohysterectomy. Ultrasonographic and radiographic examinations suggested stump pyometra or cervical granuloma and vesicovaginal fistula. Two laparotomies were performed to repair the adhesions, but no reduction in clinical signs was observed. Medical treatment was performed. Eight months later, the animal was admitted for examination and it appeared to be healthy but still had signs of strangury.
\end{abstract}

Keywords: bitch, strangury, laparotomy, ovary

\section{RESUMO}

Uma cadela de sete anos de idade foi trazida ao hospital veterinário "Governador Laudo Natel" pois apresentava estrangúria há dois meses. Os sinais clínicos desenvolveram-se dois dias após ováriohisterectomia de eleição. Exames radiográficos e ultrasonográficos sugeriram piometra de coto ou granuloma cervical e fistula vesicovaginal. Duas laparotomias foram realizadas para desfazer as adesões, mas não houve melhora nos sinais clínicos observados. Iniciou-se tratamento médico e oito meses depois o animal, novamente avaliado, apresentava-se sadio porém ainda com sinais de estrangúria.

Palavras-chave: cadela, estrangúria, lapocatomia, ovário

\section{INTRODUCTION}

Ovariohysterectomy in the bitch is a common procedure for birth control, to prevent oestrus and pseudopregnancy (Janssens, Janssens, 1991). Among elective surgeries, it is the most common and maybe for this reason, has the highest complication rate (Pollari, Bonnett, 1996; Bradley et al., 2000).

Complications common to many surgical procedures such as anaesthetic problems or delayed wound healing can occur, but are not peculiar to ovariohysterectomy. According to Pearson (1973) and MacCoy et al. (1988), the particular and usual complications of spaying are ovarian or uterine granulomas with or without fistulation, recurrent oestrus, vaginal bleeding, intestinal and peritoneal adhesions, urinary incontinence and pyometra of the uterine stump.

Urological complications are less frequent but have been the subject of several reports, usually related to inadvertent ligation or transection of part of the urinary tract (Bradley et al., 2000). There have been several reports about the

Recebido para publicação em 18 de junho de 2003

Recebido para publicação, após modificações, em 20 de outubro de 2003

*Autor para correspondência

E-mail: wilter@fcav.unesp.br 


\section{Gadelha et al.}

accidental ligation of the ureter at the time of surgery, or the involvement of a ureter in adhesions with the vagina which may lead to hydroureter, hydronephrosis and urinary incontinence (Kunin, Terry, 1980; De Baerdermaecker, 1984; MacCoy et al., 1988; Banks et al., 1991; Lamb, 1994; Neiger, Lamb, 2000). Pearson and Gibbs (1980) affirmed that it is not clear how a ureterovaginal fistula could result from hysterectomy because the structures lie in separate folds of the abdomen and are not in close apposition. Urinary incontinence is one of the most common urological complications and can occur as a consequence of a vesicovaginal fistula resulting from an accidental inclusion of the caudal bladder neck in a vaginal ligature, leading to hydroureter and hydronephosis (Ewers, Holt, 1992).

Other reports have attributed urinary incontinence to the hormonal effects of ovariohysterectomy and ovariectomy. Thrusfield (1985) observed "hormonal" urinary incontinence in 34 of 791 bitches submitted to ovariohysterectomy. Janssens and Janssens (1991) showed that 12 of 72 bitches (18\%) submitted to ovariectomy showed urinary incontinence $1-5$ years after surgery.

Considering that urological complications are uncommon problems of ovariohysterectomy, the present report describes a case of vesicovaginal fistula and vaginal bleeding following ovariohysterectomy in a bitch.

\section{CASE HISTORY}

A seven-year-old bitch was consulted in the Veterinary Hospital "Governador Laudo Natel" in the Reproduction and Obstetrics Department for the investigation of a two-month history of strangury. According to anamnesis, the animal had been submitted, in another hospital, to three surgical procedures during a two-month period.

The first surgery was a caesarean to resolve a foetal dystocia followed by ovariohysterectomy. During the post-operative period, the animal presented with strangury, tenesmus, abdominal sensitivity and hyporexia. Laparotomy (second surgery) was performed 30 days after the ovariohysterectomy with the intention of remeding adhesions in the uterine stump and bladder. The recovery period revealed continuous abdominal pain, strangury and sanguinopurulent vaginal discharge, during which the animal was treated only with analgesics to alleviate pain. Another laparotomy was planned because it was thought likely that the strangury was a consequence of the adhesions, which was confirmed.

On physical examination, the dog was apathetic, had signs of pain in the caudal portion of the abdomen, and had sanguinopurulent vaginal discharge. The abdominal pain along with vaginal stenosis did not permit a gynecological examination. Due to its clinical condition, the animal was kept in the hospital so that all the necessary examinations could be performed.

Haematologically, there was leukocytosis with a left deflection and a Hct of $24 \%$, and the serum chemistry parameters (ALT and creatinine) were normal. Ultrasound revealed a well-defined structure in the caudal portion of the abdomen, $25 \mathrm{~mm}$ in diameter, heterogeneous parenchyma, and echogenic spots in the middle, suggesting uterine stump pyometra or cervical granuloma. The use of contrast technique in the radiograph allowed the same diagnostic as that of ultrasound, and in addition revealed the presence of a vesicovaginal fistula.

The clinical treatment included antibiotic (enrofloxacin, sc) and antiinflammatory (flunixin-meglumine, sc), treatment fluidtherapy (Ringer's lactate with glucose, B complex and vitamin $\mathrm{C}$ ), blood transfusion (due to blood loss in vaginal discharge) and ergonovine maleate treatment. In the first five days of treatment, the urination had to be induced by massage and compression through abdominal palpation of the bladder, three times a day. After this period, the patient was urinating normally, and even if it still had the strangury, the frequency and the quantity of urination were normal.

After nine days of treatment, the bitch was well recovered, without vaginal discharge or abdominal pain. At that time, the haemogram was repeated and all the values were normal. The animal was discharged the next day to be treated at home with antibiotics for seven more days.

Eight months later, the dog was admitted to the hospital for general evaluation. A clinical 
examination was performed and no abnormalities were detected, except for strangury which persisted. A cystography was planned, but the urethra and the vagina could not be catheterised due to the stenosis of both structures.

\section{DISCUSSION}

The incidence of complications after ovariohysterectomy varies with the experience of the surgeon, types of suture materials and preoperative patient risk factors such as age, concurrent reproductive diseases (pyometra, for example), and non reproductive diseases including congestive heart failure (Johnston, 1991).

According to Werner et al. (1992), the use of nylon cable ties for the ligation of the ovarian pedicle and uterine body could induce tissue reaction, and later on the formation of adhesions with other abdominal organs such as intestines, ureter, bladder, and vagina. These adhesions could develop complications such as tenesmus, dysuria, urinary incontinence, fistulas and granulomas. In the present case, the dog presented with a remarkable tissue reaction, in accordance with the information from the professional who had performed the three surgeries, with expressive adhesions observed in the second surgery. It is possible that only the adhesions led to strangury, abdominal pain, tenesmus, and even, the formation of vesicovaginal fistula. It is important to point out that there was no information about the type of suture materials used for the ligation of the ovarian pedicle and uterine body as well as the condition of the organ at the moment of ovariohysterectomy. However the nylon cable ties used in celiorrhaphy is reported as an inert material that could occasionally cause some low intensity tissue reactions.

Pearson (1973) suggested that haemorrhage after ovariohysterectomy could be classified into two types: primary and secondary. Primary haemorrhage is a result of a ligature not properly placed or not tightly secured, or due to excessive traction on the uterine body which could tear the uterine vessels, among other factors. This type of haemorrhage leads to blood accumulation in the peritoneal cavity. Secondary haemorrhage could be a result of ruptured ovarian or uterine vessels or infection around the ligature due to the use of contaminated material, which would lead to vaginal bleeding a few days after surgery. In this case it was not possible to investigate the cause of haemorrhage but this kind of classification has a relative clinical importance, since any haemorrhage is a risk to the life of the animal.

De Baerdermaecker (1984) and Johnston (1991) affirmed that the purulent or sanguinopurulent vulvar discharge could be a result of retained tissue that becomes infected and inflamed, such as uterine stump granuloma. Our data are in accordance to the findings of these authors as radiography and ultrasound revealed the presence of a structure with the same characteristics of a granuloma or stump pyometra. Either of the hypotheses could be accepted since both can determine sanguinopurulent vaginal discharge

Ewers and Holt (1992) mentioned a case of a bitch submitted to ovariohysterectomy after a caesarean section, that presented with hydroureter and hydronephrosis, vesicovaginal fistula and the absence of most of the urinary bladder as postoperative complications. These authors verified that these abnormalities were a result from the ligation of the caudal bladder, at the level of the trigone, during ovariohysterectomy. It is possible that the vesicovaginal fistula in the present case, was a result of the accidental ligation of the bladder neck or urethra during ovariohysterectomy since we found a remarkable stenosis of this structure at the time of physical examination. Another possibility is that the fistula was formed in an attempt to repair the adhesions during the second laparotomy. Unfortunately, it was not possible to perform radiography using contrast due to financial limitations. This examination could have given us information about the incidence of hydroureter or hydronephosis. However, we believe that the animal did not have these complications, since eight months after the treatment, the physical, haematological and serum chemistry examinations were normal. The origin of the remarkable stenosis is still unknown but suggests intense tissue reaction due to individual factors or to the use of improper surgical materials. It was suggested that omentopexy is an important procedure, which protects the surgical site of the uterine stump, 


\section{Gadelha et al.}

avoiding formation of adhesions with adjacent organs.

In spite of most authors suggest surgical treatment, it was decided not to perform the fourth surgery owing to the general health of the patient and critical blood loss. The treatment adopted was part of that reported by Pearson (1973), and it proved efficient for animal recovery, specially the blood transfusion which improved the haematological status and the use of the ergonovine maleate which helped to drain the sanguinopurulent discharge. Treatment results were satisfactory since clinical treatment, in most cases, would not be the best method to get the recovery, specially in severe cases.

Ovariohysterectomy is a common and routine surgical procedure in clinics and veterinary hospitals, and represents a source of revenue for these institutions. Thus, as with any other surgery procedure, ovariohysterectomy needs technique experience, surgeon know-how and proper use of materials to avoid postoperative complications

\section{REFERENCES}

BANKS, S.E.; FLEMING, I.R.; BROWNING, T.N. Urinary incontinence in a bitch caused by vaginal ureteral fistulation. Vet. Rec.,v.128, p.108, 1991.

BRADLEY, K.J.; BILLET, J.P.; BARR, F.J. Dysuria resulting from an encapsulated haematoma in a recently spayed bitch. J. Small Anim. Pract., v.41, p.465-467, 2000.

De BAERDEMAECKER, G.C. Post spaying vaginal disgharge in a bitch caused by acquired vaginoureteral fistula. Vet. Rec., v.115, p.62, 1984.

EWERS, R.S.; HOLT, P.E. Urological complications following ovariohysterectomy in a bitch. J. Small Anim. Pract.,v.33, p.236238,1992 .

JANSSENS， L.A.A.; JANSSENS， G.H.R.R. Bilateral flank ovariectomy in the dog- surgical technique and sequelae in 72 animals. J. Small Anim. Pract., v.32, p.249-252, 1991.

JOHNSTON, S.D. Questions and answers on the effects of surgically neutering dogs and cats. $J$. Am. Vet. Med. Assoc., v.198, p.1206-1214, 1991.

KUNIN, S.; TERRY, M.A. Complication following ovariohysterectomy in a dog. Vet. Med.: Small Anim. Clin., p.1000-1001, 1980.

LAMB, C.R. Acquired ureterovaginal fistula secondary to ovariohysterectomy in a dog: diagnosis using ultrasound-guided nephropyielocentesis and antegrade ureterography. Vet. Radiol. Ultras., v. 35, p.201203, 1994.

MACCOY, D.M.; OGILVIE, G.; BURKE, T. et al. Postovariohysterectomy ureterovaginal fistula in a dog. J. Am. Anim. Hosp. Assoc., v.24, p.469$471,1988$.

NEIGER, R.; LAMB, C.R. Retrograde vaginographie zur diagnose einer ureterovaginalen fistel nach ovariohysterektomie: zwei Fälle. Schwiz. Arch. Tierheilk., v. 142, p.529-533, 2000.

PEARSON, H. The complications of ovariohysterectomy in the bitch. J. Small Anim. Pract., v. 14, p.257-266, 1973.

PEARSON, H.; GIBBS, C. Urinary incontinence in a dog due to accidental vagino-ureteral fistulation during hysterectomy. J. Small Anim. Pract., v.21, p.287-291, 1980.

POLLARI, F.L.; BONNETT, B.N. Evaluation of postoperative complications following elective surgeries of dogs and cats at private practices using computer records. Can. Vet. J., v.37, p.672-678, 1986.

THRUSFIELD, M.V. Association between incontinence and spaying in bitches. Vet. Rec., v.116, p.695, 1985.

WERNER, R.E.; STRAUGHAN, A.J.; VEZIN, D. Nylon cable band reactions in ovariohysterectomized bitches. J. Am. Vet. Med. Assoc., v.200, p.64-66, 1992. 